\title{
International Journal of Economics and Financial Issues
}

ISSN: 2146-4138

available at http: www.econjournals.com

International Journal of Economics and Financial Issues, 2019, 9(1), 217-224.

\section{Industry Structure, Bank Adequacy, Operational Efficiency: Financial Performance Applied Study on the Islamic Banks Listed in Bahrain Stock Exchange}

\author{
Tharwah Shaalan* \\ Department of Finance and Economics, Business Administration Faculty, Taibah University, KSA. *E-mail: tharwasholan@yahoo.com
}

Received: 02 November 2018

Accepted: 04 January 2019

DOI: https://doi.org/10.32479/ijefi.7452

\begin{abstract}
The purpose of this study is to test the relationship between the market power variables and the bank concentration of Islamic banks registered in Bahrain stock exchange, using the HHI index of loans, in addition to other variables such as bank solvency, operational efficiency and financial leverage on the financial performance of these banks, which are represented by the return on assets and the efficiency of lending profitability using regression data panel analysis. To test the hypotheses of this study, the researcher employed the multiple regression method as well as the same using the panel data. The results of this applied study determined a fundamental impact exerted by the bank's capital adequacy and market share on the rate of return on assets as well as the intrinsic effect of operational efficiency variables and bank concentration to contribute to the efficiency variable of lending to these banks.
\end{abstract}

Keywords: Islamic Banks, Bank Performance, Financial Performance, Market Power, Market Concentration

JEL Classifications: C23, G21, L11

\section{INTRODUCTION}

The structure-behavior-performance model is one of the most important models employed in the field of industrial economics, which has been used by companies and financial institutions at the macro level of the economy by measuring the market shares of these enterprises, the ratio of concentration in an industry and the impact of sector-wide indicators on the performance of these industries. Furthermore, this model is presented by Mason in order to explain and analyze the profitability of industrial enterprises through market structures that affect the same.

\section{REVISION OF THE THOREY IN THE FILELD OF INDUSTRIAL ECONOMICS}

\subsection{Conduct of Enterprises in the Industry}

The conduct of enterprises in the industry by means of the policies are pursued by these enterprises under the dominant industry structure and their conditions of demand and behavior towards other competitive enterprises in order to achieve the objectives of these enterprises. This includes the most important behavioral policies adopted by enterprises in the industry: Pricing policies for products, policies concerning the quantity of production, production development policies and/or sales policies.

Behavior is the link between the industry's dominant structure, which has the following three main dimensions: Degree of industrial concentration, entry barriers to industry, product excellence and performance levels of enterprises in the industry, the most important of which include the level of profitability, production efficiency and technical development rate.

\subsection{Factors Influencing the Behavior of Enterprises in} the Industry

Although the behavior of modern enterprises in the industry is affected by several non-economic factors and considerations 
(e.g., political, social, and so on), the most important economic factors that affect the same can be identified as follows.

\subsubsection{Structure of the industry}

The degree of concentration in industry is only an indicator that provides a picture of an important aspect of the industry's structure. Moreover, it indicates some cases where the control of certain enterprises can prevail over the market. However, this level of analysis is not enough if we do not possess adequate information about the relevant factors in order to influence the level of concentration as entry barriers or the degree of excellence of products. The control of a single facility in an industry cannot maintain its status unless it has the capacity to reduce production costs, product excellence or other barriers to entry into the industry. Finally, the structure of the industry provides us with information pertaining to the following:

- Number of enterprises in the industry;

- Proportional distribution of the industry's total size among existing enterprises;

- The extent and intensity of impediments faced by new enterprises for entry into the industry;

- Degree of excellence of enterprise products in the industry.

\subsubsection{Objectives of the facility}

The objectives of this establishment are numerous, and these goals affect the direction and performance of their behavior.

From a partial perspective, the traditional objective of the enterprise's partial theory is to achieve maximum profit. Furthermore, owing to the complexity of the environment in which the facility is located, the goal of maximizing the profit is a minor one. This is due to the lack of accurate expectations regarding the enterprise's behavior because of the increased likelihood of uncertainty (risk) in calculating the expected profitability, given the breadth of the shareholding companies, the resulting break-up of the administration from ownership and the resultant conflicting interests of different parties in overriding one objective, while retaining a minimum set of multiple objectives. For these reasons, the real objectives of the modern facility, as observed by several specialists, are as follows:

1. Maximizing revenue to maintain the business share in the local market;

2. Fulfilling management objectives, including job satisfaction, salary development or rewards;

3. Achieving the highest growth rate concerning the company's sales;

4. Maintaining the financial position of the facility, which includes sacrificing some profits in exchange for maintaining a minimum liquidity;

5. Maintaining the margin of safety; this objective reflects the expectations of decision-makers and their propensity to or dislike for risks.

\subsubsection{Volume and flexibility of demand}

The degree of concentration in the industry is often influenced by changing demands as well as changes in market size, resulting from changes in commodity demand, which are key factors in the effectiveness of entry barriers to the industry. Moreover, price elasticity is a critical factor in enterprise policy, pricing and the relationship of demand curves to the market in which the enterprise operates and is confronted (full competition, monopoly, monopoly competition or competition between select few) (Bamkharmeh, op. cit., 120-34). The following Figure 1 presents some of its basic elements.

It is not necessary to have simple one-way relationships that move in the direction of the structure with regard to managerial behavior-performance, which signify the only relationships that can exist between the said relationships. This means that there can be a correlation between these variables in the opposite direction or in both directions (Clark, 1994. p. 19-21).

The researcher envisages that interventional relationships exist under this model as well as a series of influences from the underlying conditions (for instance, costs and their impact on efficiency, concentration and then performance) or a combination of relational relationships between these variables combined. These relationships can be conceived as found in the path analysis.

The researcher considers that it is useful to review the theoretical and intellectual framework on which the industrial concentration portal is based for linking the market structure, to conduct and subsequently perform, which represents the pricing in the oligopolistic market. Furthermore, the French study conducted by Cournot et al. (1838) is the leading study in the field of pricing in

Figure 1: Structure - management behavior - performance model

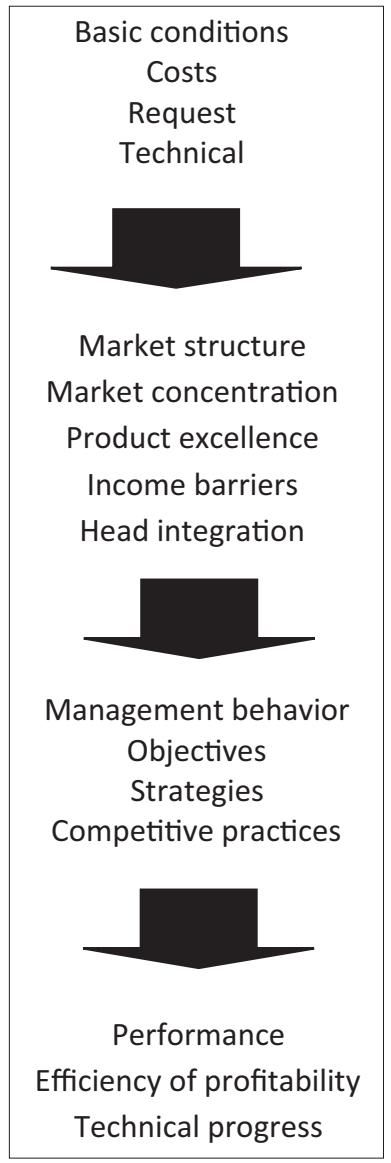

(Roger Clareck, 20, 1994) 
the said market. Presumably, in this model, each facility maximizes its profits by imposing the firm's competitive production stability. In addition, the core note assumes that each facility does not anticipate any change in the production of its competitors in response to the change in its production. It also assumes that the entry of new facilities to the industry will reduce the price and the power of the company. Irrigation for establishments is already prevalent in the industry.

Bertrand (1883) was the first to criticize the core note model from Peterborough's point of view; enterprises may be interested in their competitors' prices rather than their level of production. Furthermore, Petra demonstrates the balance of the market in the case of a homogeneous product. If an enterprise in one of the markets initially identified a high price and followed Petra's end model, which expects to acquire the market if its price is lowered by imposing the price stability of the enterprises competing for what they are and if all enterprises think in the same way, their prices fall until they reach the balance of Peterborough at the price of full competition. This happens even if the number of such enterprises includes only two facilities.

Edgeworth (1925) had agreed with Petrand in his model with respect to the assumption that no intuitive changes were there in the price. However, he disagreed with it wherein it was assumed to be impossible to acquire a single facility on the market; hence, the market would not reach the price of full competition, and no balance price in the model of the Edgrath was there.

Von Stackelberg (1934), the German researcher, analyzed the state of evidence in the competition market between the two establishments. Moreover, the affiliate in this model is a facility in the core note model, which determines the volume of production that achieves maximum profit, considering that the volume of production of the competitive plant remains constant. The pilot facility anticipates that the facility will behave as a competitor. The said model assumes that each facility behaves as a guide or follower and chooses its role on the basis of maximizing profitability.

Chamberlin (1961) states that the establishments in the oligopolistic market must seek to reach full coordination from Chamberlain's perspective. Furthermore, in the case of two or more installations and if there is no merger between them, we are likely to observe a price level close to the price of the monopoly. In general, such cooperation or coordination between enterprises may vary depending on the number of firms and the degree of concentration of the market. Moreover, the increased focus leads to increased cooperation and coordination between enterprises. The behavior of enterprises varies between full competition and integration, depending on the degree of market concentration.

With regard to the dominant model of the establishment, unlike Stakelberg's model wherein the affiliated facility adopts the competitor's course in Cornett's model, here the affiliate takes the competitor's course under full competition. This is because this model assumes that the affiliate will consider the market price as a constant and produce when this price is equal to its marginal cost.
Furthermore, the dominant establishment determines the price that maximizes its profits, taking into account the production of competitive enterprises. It acts as a monopoly but is constrained by what competitors produce. Moreover, it is unable to obtain the highest profit for the industry (Clark, 1994. p. 84).

One of the entry points to assess the performance of commercial banks is the approach based on linking commercial banks' profitability and subsequently performing it with the market's structure and/or efficiency. This has been dealt with in several studies in the framework of the literature concerning industrial economy. The high concentration of the market, i.e., the small number of institutions or market shares equals and/or facilitates collusion, thus enabling the establishments to nearly reach the limit of total monopoly (maximizing shared profits) (Clark, 1994. p. 169).

In the first direction, it is recognized that market structure is the determinant of business behavior in terms of pricing of its goods and services and dependence on its earning of market power, based on its profitability's degree of concentration. This is often above normal profits and often occurs at the expense of the community's welfare (Heggestad, 1979). It is included among the 36 studies conducted on the American banking industry, 23 of which found evidence supporting the premise of market concentration. Studies supporting this trend confirmed that US banks, during the various periods in which these studies were conducted, have generated extraordinary profits by virtue of market concentration.

It should be noted that subsequent studies have illustrated some of the shortcomings of certain studies, as explained by Gilbert (1984) and Ostorne and Wendel (1983). The previous studies suffered from numerous defects, including the lack of stability. In addition, they did not take into account the privacy of the banking industry that regulates its business. This depends on the lack of freedom for new competitors to enter the industry, so that the concentration of the market does not necessarily have to be the result of collusion and subsequently profits. This is because the latter is only valid if there are no impediments to the entry of new competitors in the industry.

The second trend, which focuses on the premise of the facility's efficiency, finds that it comes in two ways, with the first hypothesis focused on administrative efficiency and production technology, the second of which was performed with the efficiency of the first image and the supporters of the initial photograph (Evanoff and Fortier, 1988). This affirms that business enterprises with high administrative efficiency and/or those with efficient production technology are able to earn high market shares by virtue of their savings in operating costs. Hence, they are able to make an extraordinary profit.

The hypothesis concerning the facility's efficiency in its second form (volume efficiency), which is advocated by Peltzman (1977), confirms that all business enterprises have the same level of technical managerial competence but differ in terms of their ability to produce efficiently, with levels of volume (body savings) inevitably resulting in the generation of high profit. 
Many of the cost and efficiency studies regarding commercial banks of various sizes suggest that the relationship between the bank's size, as measured by the size of its assets or deposits and the production cost of the input unit, should be close to the efficiency of the maximum size. As large banks usually rely on the provision of various financial services different from those offered by medium and small-sized banks, large banks that are supposed to work to attain lower operating costs benefit from their operating range or size.

Most studies have confirmed that most banks do not work at the lower cost level. Moreover, they assert that the efficiency of inputs (x-efficiency) is between $20 \%$ and $25 \%$ of the total cost of production to be considered under the conditions of maximizing efficiency, in addition to the fact that the most risky banks are often less efficient on an average. However, for the banking industry, access to lower operating costs and higher efficiency is linked to the different motives of both managers and owners, inter alia. While the owners seek to reach the lowest cost possible and then increase profits and maximize their market share value, managers tend to maximize growth and increase their market share. Furthermore, in most enterprises relating to banking finance, we find that bank managers tend to prefer expenses in a way that overwhelms the owners' desire to increase and/or maximize the return. In addition, the same is observed in case of different banks from other financial establishments in the industrial sector owing to the use of large leverage in relation to the right of ownership (Rose, pp. 95-97).

\section{EMPIRICAL LITERATURE}

Altberger's and Kim study (1994) titled the reliability of oligopolies, the structure of productivity in banks: A practical evaluation employed the comprehensive inventory method for all banks in Norway and to divide banks into groups by size according to their total assets, using multiple regression. This study found that each bank relies on the reactions of its competitors and that there is a direct correlation between the market share and profitability of banks for all groups.

Molyneux and Thornton's (1994) research aimed at studying the impact of the market share, the concentration indices of assets and deposits on the profitability of European banks; the study was titled Reference to the determinants of profitability of commercial banks. Furthermore, by using a sample of 96 banks in Spain and employing the multiple regression method, the researchers ascertained a negative impact that was statistically significant for the bank's market share on profitability indices. In addition, they identified a positive impact that was statistically significant for the degree of bank concentration on the rate of return on assets, which means that large banks can price their services in a way that enables them to generate extraordinary profits.

Hannan's (1997) study examined whether the Herfindahl Hirschman index (HHI) was sufficient to estimate and calculate the variation of the market share and the number of competitors, to interpret and clarify the interest rate on deposits and loans using regression analysis, multiplayer. One of the outcomes of this study was the interpretation of the market share and the number of competitors for bank pricing, while the indicator did not explain it.
Berger's study (1995) titled Interest rates on deposits and the local concentration market, which was applied to a sample of 4800 American banks for the period 1980-1990, found a direct correlation between the banks' market share and their profitability. This means that large banks exploit their market power with regard to raising prices and increasing profits, while there is no moral correlation between the degree of concentration and profitability.

Simon's and Roger study (1999) titled Market share, concentration and diversity in company profitability contradicted the previous study with respect to a positive relationship between concentration and profitability while not finding a relationship between market share and profitability.

In another study (Berger and Rosen, 2001) titled The impact of market size structure on competition: The status of lending to small enterprises, the researchers aimed to study the impact of market size's structure on the pricing of loans for small enterprises. Moreover, they examined the division of banks according to different sizes $(<\$ 100$ million), Volume 1 (more than 100 to $<\$ 1$ billion), Volume 2 ( $\$ 1$ billion- $\$ 10$ billion) and Volume 3 ( $>\$ 10$ billion). One of the primary outcomes of this study is the impact of the market size's structure on the pricing of small enterprise loans, while there is no impact of the banks' size on the pricing of large enterprise loans. Moreover, the structure of the market size affects the pricing of loans in large banks than in small.

Contrary to the findings of the previous study, Sturm and Williams' study (2005) adopted a border-efficiency approach to assess the efficiency of foreign banks in Australia and subsequently used a maximum analysis to determine the competency model for foreign banks, supporting the hypothesis of Berger, et al.'s study (2005) concerning the benefits and relativity of this study. This study also finds that British banks are more efficient than others, and the market shares enjoyed by local banks restrict and limit the entry of other banks into industry. Furthermore, they serve as the reason for the low efficiency of foreign banks.

Scholtens' research (2000) titled competition, growth and performance concluded that the profitability of banks is linked to the size of their assets, with an inverse relationship, and it has a positive relationship to the banks' capital.

Pilloff and Rhoades' study (2002) confirmed the same results as the previous study, wherein the researchers found that the $\mathrm{HHI}$ index of the local market and the number of large banks is related to profitability.

Yu's study (2004) verifies the premise of the structure-behaviorperformance model and that of a sample of German banks for the period between 1998 and 2002. Moreover, the study finds what supports this hypothesis, as the profitability of German banks increases with the increase of their size or by the occurrence of bank mergers. In addition, the profitability of banks not only increases the concentration but is also efficient in terms of its size. Furthermore, the risk of the lending portfolio is defined by the relationship between structure and profitability.

Derasiy and Daltung (1998) and Ennis (2001) presented a theory to achieve the optimal size of banks from the macro perspective, in 
order to overcome the problems pertaining to market concentration. On the other hand, In Derasiy and Daltung's study (1998) titled The optimal size of the bank: Costs and the advantages of diversification regarding the diversification and financial structure of banks, the researchers believe that by diversifying the bank's portfolio and engaging in debt financing, the bank can commit to a high level of control. Moreover, this could be done by linking costs to the benefits of diversification, highlighting the cost problem by increasing the burden of controlling more loans. Furthermore, the burden of censorship depends on the motivation of the controlled agent. If the bank finances its loans from its deposits, it will share the profit with the investor and bear the costs alone. However, in the event that the bank finances its loans by debt, diversification increases the incentive and returns to the bank as long as it does not fail.

Iveta (2012) aimed to estimate the market power in the Czech banking industry during 2000-2010. This paper applied the HHI and the concentration ratio. The values of the HHI and concentration ratio show a trend of modest decrease, meaning that market concentration changed appreciably over the sample period.

The primary objective of Anarfo's study (2015) was to examine whether capital structure affects banks' performance in sub-Sahara Africa and to examine the nature of relationship between capital structure and bank performance. Its result found that a bank's performance does not depend on its capital structure from the above analysis.

Pinto, et al. (2017) examined the impact of capital structure on the financial performance with reference to the banking industry in India. This study's results indicate that the capital structure has a significant impact on the financial performance of the banks. We conclude that while designing capital structure and financing activities, banks should select an optimum mix of debt (Figure 2).

\section{DATA AND METHOLOGEY}

The said framework employs the method of panel (data) discriminant analysis (Stata.V.14) and the method of Panel (data) multiple linear regression (Stata.V.14). The study period is 10 years, starting from 2006 and ending in 2015.

\subsection{Description of the Variables in Part I}

\subsubsection{Interpreted variables}

1. Bank adequacy (CA): This variable reflects the sufficiency of the bank's capital, weighted by the asset risk weights reflecting the degrees and levels of risk in accordance with the Basel II classification of banks.

2. Market share of loans (MSLOAN): This variable presents the bank's share of lending in relation to the total market shares of lending to the banks combined.

3. HHI of loans (IHHLOANS2): This variable signifies the square market share of the banks combined using the HHI index.

\subsubsection{Dependent variable (ROA)}

This variable includes the bank's profit after the tax is divided by the total number of assets.

\subsection{Mathematical Model \\ $\mathrm{ROA}=\alpha+\mathrm{CA}+\mathrm{MSLOAN}+\mathrm{IHHLOAN}^{2}+\varepsilon$}

\subsection{Hypotheses of Part 1}

- $\mathrm{H}_{0}$ : There is no significant statistically impact of bank capital adequacy, market share and bank concentration variables on the rate of return on assets.

- $\mathrm{H}_{0}$ : The independent variables are independent of one another.

- $\mathrm{H}_{0}$ : The residuals are distributed naturally.

We reject the zero hypothesis $\left(\mathrm{H}_{0}\right)$ and accept the alternative imposition of an existent significant statistically impact of bank capital adequacy, market share and bank concentration variables on the rate of return on assets. Table 1 showed the regression model with P > F (1 0.000), Adj R-squared (0.524), moreover, it depicted the coefficient significance of AC, MSLOAN and IHHLOAN2 as well as a constant, which all reached 0.000, as shown by Table 2. Furthermore, a negative relationship exists between capital adequacy and market share of loan on the rate return of assets, whereas there is a positive relationship between market loan concentration on the rate return of assets.

Figure 2: Market share and concentration

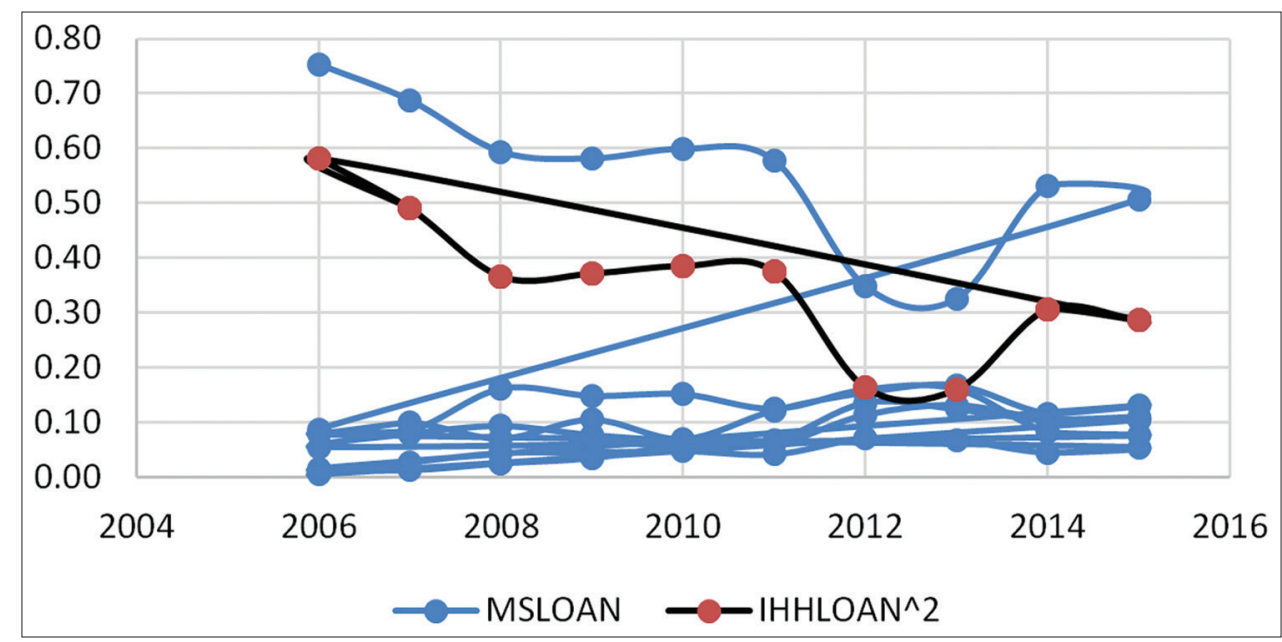


In addition, the accepted hypothesis two assessed that the independent variables are independent of each other. Table 3 proved this hypothesis by using the variance inflation factor (VIF); the mean VIF was 1.36 .

Furthermore, this study rejected hypothesis three; its result approved that the residuals are not normally distributed, as shown in Table 4, which presented the Shapiro-Wilk W test for normal data; $P>0.05$. Moreover, Figure 3 concerning the residuals plot demonstrated that the residuals were not normally distributed.

\section{Table 1: ANOVA summary}

\begin{tabular}{lcc} 
Source & SS & df \\
Model & 0.308 & 3 \\
Residual & 0.253 & 56 \\
Total & 0.561 & 59 \\
Number of obs & 60 & \\
F & $(3,56)$ & \\
P $>$ F & 0.000 & \\
R-squared & 0.548 & \\
Adj R-squared & 0.524 & \\
Root MSE & 0.0672 & \\
\hline
\end{tabular}

Table 2: Regress ROA (MSLOAN IHHLOAN2 CA)

\begin{tabular}{lccc} 
ROA & Coef & Std. Err & $\mathbf{P}>|\mathbf{t}|$ \\
CA & -0.97 & 0.05 & $0.000^{* *}$ \\
MSLOAN & -0.29 & 0.06 & $0.000^{* *}$ \\
IHHLOAN2 & 0.36 & 0.11 & $0.000^{* *}$ \\
- cons & 0.145 & 0.04 & $0.001^{* *}$ \\
\hline
\end{tabular}

$* \mathrm{P}>0.05, * * \mathrm{P}>0.01$

Table 3: VIF test

\begin{tabular}{lll} 
Variable & VIF & $\mathbf{1 / V I F}$ \\
CA & 1.48 & 0.673 \\
MSLOAN & 1.48 & 0.673 \\
IHHLOAN2 & 1.10 & 0.911 \\
Mean VIF & 1.36 & \\
\hline
\end{tabular}

Table 4: Shapiro-Wilk $W$ test for normal data

\begin{tabular}{lccccc} 
Variable & Obs & W & $\mathbf{V}$ & $\mathbf{Z}$ & $\mathbf{P}>\mathbf{Z}$ \\
Residual & 60 & 0.863 & 7.419 & 4.320 & 0.00001 \\
\hline
\end{tabular}

Figure 3: Residuals plot, Y line (0)

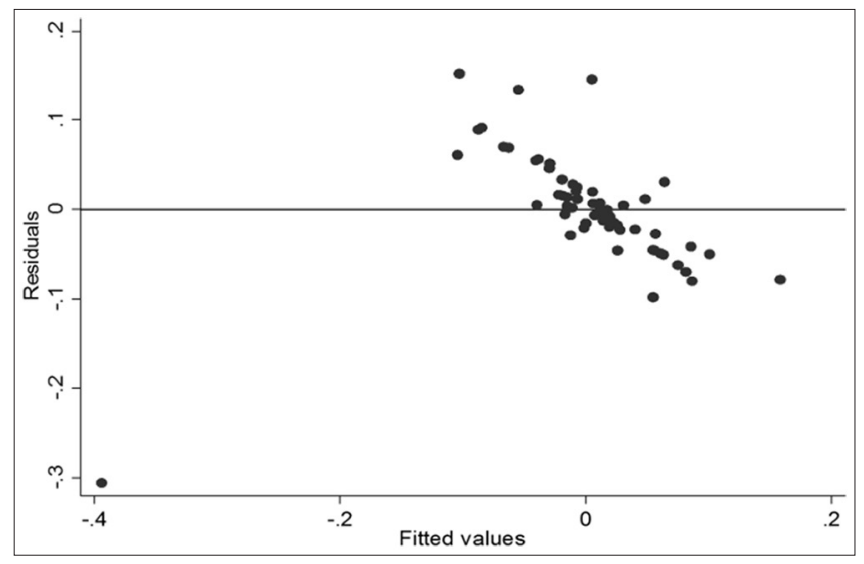

Panel random-effects GLS regression of ROA on CA, MSLOAN, IHHLOAN2, presented as R-sq., was 0.52 in Table 5 and confirmed the same results in Tables 1 and 2.

\subsection{Description of the Variables in Part 2}

4.4.1. Interpreted variables

1. Bank adequacy (OE): This variable reflects the efficiency pertaining to the operational efficiency of banks.

2. Market share of loans (MSLOAN): The variable presents the bank's share of lending in relation to the total market shares of lending to the banks combined.

3. HHI of loans (IHHLOANS2): This variable includes the square market share of the banks combined using the HHI index.

\subsubsection{Dependent variable (EROL)}

This variable reflects the profitability efficiency of lending to the banks by calculating the best profitability of lending in a given year at the combined bank level.

\subsection{Mathematical Model}

$\mathrm{EROL}=\alpha+\mathrm{OE}+\mathrm{MSLOAN}+\mathrm{IHHLOAN}^{2}+\varepsilon(2)$

\subsection{Hypotheses of Part 2}

- $\mathrm{H}_{0}$ : There is no statistically significant impact of the banks' operating efficiency, market share and bank concentration variables on the rate of return concerning the efficiency of loan profitability.

- $\mathrm{H}_{0}$ : Independent variables are independent of each other.

- $\mathrm{H}_{0}$ : The residuals are distributed naturally.

The results of this study rejected null hypotheses partially and accepted the alternative imposition of an existent significant statistically impact of operating efficiency and bank concentration variables on the rate of return regarding to efficiency of loan profitability. Moreover, there is no evidence of a significant impact of market loan share on the rate of return pertaining to the efficiency of loan profitability.

Table 6 shows the regression model with P > F (1 0.000), Adj $\mathrm{R}$-squared (0.524). Furthermore, it presents the significance of the coefficient of OEC, IHHLOAN2 and a constant, which all reached the value 0.000 , unless MSLOAN was 0.188 . Moreover, there is a negative relationship between operating efficiency on the return of efficiency of loan profitability. Conversely, there is positive relationship between market loan concentration on the return of efficiency of loan profitability.

In addition, the accepted hypothesis two assessed that the independent variables are independent of one another. Table 7 proved this hypothesis by using the VIF; the mean VIF was 1.36 .

Moreover, this study rejected hypothesis three; the results asserted that the residuals are not normally distributed, as shown in Table 4 that presents the Shapiro-Wilk W test for normal data; $\mathrm{P}<0.05$. Moreover, Figure 4 concerning the residuals plot reflected that the residuals were not normally distributed. 
Table 5: Panel random-effects GLS regression of ROA on CA, MSLOAN and IHHLOAN2

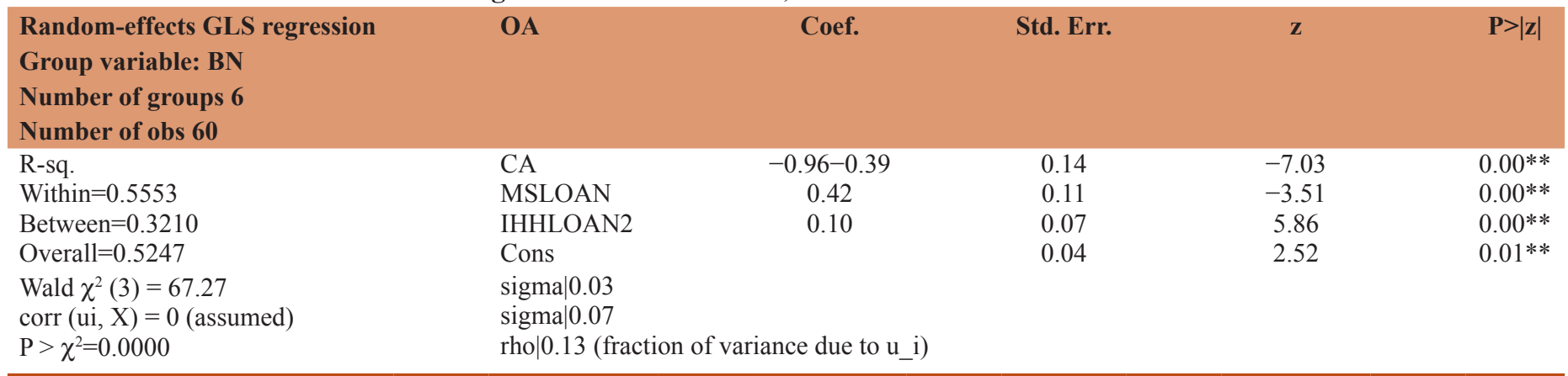

$* \mathrm{P}>0.05, * * \mathrm{P}>0.01$

Table 6: ANOVA summary

\begin{tabular}{lcc} 
Source & SS & df \\
Model & 0.221 & 3 \\
Residual & 0.071 & 56 \\
Total & 0.291 & 59 \\
Number of obs & 60 & \\
F & $(3,56)$ & \\
P $>$ F & 0.000 & \\
R-squared & 0.759 & \\
Adj R-squared & 0.746 & \\
Root MSE & 0.0353 & \\
\hline
\end{tabular}

Table 7: Regress EROL OE MSLOAN IHHLOAN2

\begin{tabular}{lccc} 
EROL & Coef. & $\mathbf{t}$ & $\mathbf{P}>|\mathbf{t}|$ \\
OE & -0.091 & -3.31 & $0.002^{* *}$ \\
MSLOAN & 0.0361 & 1.33 & 0.18 \\
IHHLOAN2 & 0.429 & 10.82 & $0.000^{* *}$ \\
cons & 0.065 & 2.70 & $0.009 * *$ \\
\hline
\end{tabular}

$* \mathrm{P}>0.05, * * \mathrm{P}>0.01$

Table 8: VIF test

\begin{tabular}{lll} 
Variable & VIF & $\mathbf{1 / V I F}$ \\
OE & 1.34 & 0.744 \\
MSLOAN & 1.20 & 0.836 \\
IHHLOAN2 & 1.15 & 0.870 \\
Mean VIF & 1.23 & \\
\hline
\end{tabular}

Table 9: Shapiro-Wilk W test for normal data

\begin{tabular}{lccccc} 
Variable & Obs & W & $\mathbf{V}$ & $\mathbf{z}$ & $\mathbf{P}>\mathbf{z}$ \\
Reside & 60 & 0.96491 & 1.907 & 1.392 & 0.08198 \\
\hline
\end{tabular}

Panel random-effects GLS regression of EROL on OE, MSLOAN and IHHLOAN2, as presented in Table 5, showed that the overall R-sq. was 0.7596 and confirmed the same results in Tables 6-10.

\section{FINDINGS AND DISCUSSION}

The results of part one proved that, there was existent significant statistically impact of bank capital adequacy, market share and bank concentration variables on the rate of return on assets.

The results of part two also rejected null hypotheses partially and accepted the alternative imposition of an existent significant statistically impact of operating efficiency and bank concentration
Figure 4: Residuals plot, Y line (0)

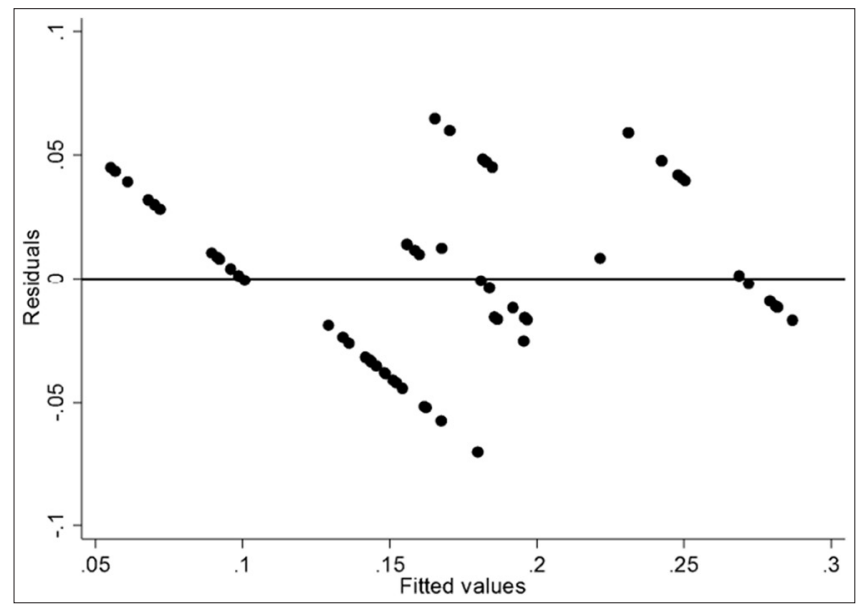

variables on the rate of return regarding to efficiency of loan profitability. Moreover, there is no evidence of a significant impact of market loan share on the rate of return pertaining to the efficiency of loan profitability.

\section{CONCLUSION}

This study aimed to test the hypothesis concerning the influence of market power and the banking concentration of lending to Islamic banks. Moreover, it examined a set of variables regarding bank solvency and operational efficiency, which are registered in Bahrain Stock Exchange; it studied their impact on the financial performance of these banks once the impact of both market power and banking concentration was tested, along with the aforementioned variables. Furthermore, the results of this study found a statistically significant inverse effect of the bank solvency variables and market share of lending, in conjunction with a positive impact of the bank concentration variable on the rate of return on assets.

Moreover, this study also found a fundamental inverse effect of the variable concerning operational efficiency and the positive impact of the bank concentration variable on the efficiency of lending to these banks. This explains that market power is not the reason behind the profitability of these banks represented by the rate of return on assets. It also explains that banking concentration is the factor that affects the efficiency of lending theaters. This is due 
Table 10: Random-effects GLS regression of EROL

\begin{tabular}{|c|c|c|c|c|c|}
\hline $\begin{array}{l}\text { Random-effects GLS regression } \\
\text { Group variable: BN } \\
\text { Number of groups } 6 \\
\text { Number of obs } 60\end{array}$ & EROL & Coef. & Std. Err. & z & $\mathbf{P}>|\mathbf{z}|$ \\
\hline $\begin{array}{l}\text { R-sq. } \\
\text { Within }=0.0000 \\
\text { between }=0.0000 \\
\text { overall }=0.7596\end{array}$ & $\begin{array}{l}\text { OE } \\
\text { MSLOAN2 } \\
\text { IHHLOAN2 } \\
\text { Cons }\end{array}$ & $\begin{array}{l}-0.09 \\
0.04 \\
0.45 \\
0.04\end{array}$ & $\begin{array}{l}0.07 \\
0.04 \\
0.43 \\
0.07\end{array}$ & $\begin{array}{c}-3.31 \\
1.33 \\
10.82 \\
2.70\end{array}$ & $\begin{array}{l}0.00^{* *} \\
0.18 \\
0.00^{* *} \\
001 * *\end{array}$ \\
\hline
\end{tabular}

$* \mathrm{P}>0.05, * * \mathrm{P}>0.01$

to other factors related to the pricing of lending services offered by these banks.

\section{REFERENCES}

Altberger, S., Kim, M. (1994), Oligopolistic interdependence and structure of production in banking: An empirical evaluation. Journal of Money, Credit Banking, 2, 309-315.

Anarfo, B. (2015), capital structure and bank performance - Evidence from Sub-Saharan Africa. European Journal of Accounting, Auditing and Finance Research, 3(3), 1-20.

Berger, A. (1995), The profit-structure relationship in banking tests of market power and efficient structure hypotheses. Journal of Money, Credit and Banking, 27(2), 40-431.

Berger, A., Rosen, R. (2001), The Effect of Market Size Structure Competition: The Case of Small Business Lending, Federal Reserve Bank of Chicago, Working Paper Series. p1-26.

Berger, A.N., Bonime, S.D., Goldberg, L.G., White, L.J. (2005), The dynamics of market entry: The effect of mergers and acquisition on entry in a banking industry, The Journal of Business, 77(4), 797-834.

Bertrand, A. (1883), Book review of Cournot's work. Journal des Savants, 24, 499-508.

Chamberlin, E.H. (1961), The Theory of Monopolistic Competition. $8^{\text {th }}$ ed. Cambridge: Harvard University Press

Clark, R. (1994), Economics Industry, Review: Ani Suleiman Kamal. Riyadh: Mars House.

Cournot, A., Bacon, A.N., Fisher, I. (1838), Researches into the mathematical principles of the theory of wealth. The Economic Journal, 8(29), 111-114.

Derasiy, V., Daltung, S. (1998), The optimal size of bank: Costs and benefits of diversification. European Economic Review, 44(9), 1701-1726.

Edgeworth, F.Y. (1925), The Pure Theory of Monopoly, (1897), Papers Relating to Political Economy. London: Macmillan.

Ennis, M. (2001), On the size distribution of banks. Federal Reserve Bank of Richmond Economic, 87(4), 1-25.

Evanoff, D., Fortier, D. (1988), Revaluation of the structure-conduct- performance paradigm in banking, Journal of Financial Services Research, 1(3), 277-294.

Gilbert, R. (1984), Bank market structure and competition: A survey. Journal of Money, Credit and Banking, 4(2), 617-645.

Hannan, T.H. (1997), Market share in equality, the number of competitors, and HHI: An examination of bank pricing. Review of Industry Organization, 38, 127-140.

Heggestad, A. (1979), Bank market structure and competition: Comment. Journal of Money, Credit and Banking, 16(4), 645-650.

Iveta, R. (2012), market power in the Czech banking sector. Journal of Competitiveness, 4(1), 1143-1154.

Molyneux, P., Thronton, J. (1994), Determinants of European bank profitability: A note. Journal of Banking and Finance, 16, 1173-1188.

Roger, C. (1994), In: Al-Any, K., Dar Almarikh, A. Industrial Economics. New York: New York University Press.

Rose, P., Hugins, S. (2005) Bank Management and Financial Services. $6^{\text {th }}$ ed. New York: Hill Companies, Inc.

Peltzman, S. (1977), The gains and losses from industrial concentration. Journal of Law and Economics, 25(2), 229-263.

Pilloff, S.J., Rhoades, S.A. (2002), Structure and profitability in banking markets. Review of Industrial Organization, 20(1), 81-98.

Pinto, P., Hawaladar, I., Quadras, J.M., Joseph, N.Y. (2017), Capital structure and financial performance of banks. International Journal of Applied Business and Economic Research, 23(2), 302-310.

Scholten, B. (2000), Competition, Growth, and Performance in the Banking Industry. Available from: http://www.eco.rug.nl/medewerk/scholten.

Simon, F., Roger, M. (1999), Market Share, Concentration and Diversification in Firm Profitability, Melbourne Institute, Working Paper 20/90. p1-40.

Sturm, J., Williams, B. (2005), What Differences in Foreign banks efficiency ?Australian Evidence, 1587, 1-34.

Von Stackelberg, H. (1934), Mark Form und Gleichgewicht, Vienna: Springer.

Yu, P., Neus, W. (2004), Market Structure, Scale Efficiency and Risk as Determinants of German Banking Profitability. Belgium: Faculty of Economics and Business, Department of Banking, University of Tuebingen Germany. p1-36. 